\title{
The Importance of Determining Carbon Sequestration and Greenhouse Gas Mitigation Potential in Ornamental Horticulture
}

\author{
S. Christopher Marble ${ }^{1}$ \\ Auburn University, Department of Horticulture, 101 Funchess Hall, Auburn, \\ Auburn, AL 36849
}

\author{
Stephen A. Prior ${ }^{2}$, G. Brett Runion ${ }^{3}$, and H. Allen Torbert ${ }^{4}$ \\ USDA-ARS National Soil Dynamics Laboratory, 411 S. Donahue Dr. Auburn, \\ $A L 36832$
}

\author{
Charles H. Gilliam ${ }^{5,7}$ and Glenn B. Fain ${ }^{6}$ \\ Auburn University, Department of Horticulture, 101 Funchess Hall, Auburn, \\ AL 36849
}

Additional index words. carbon dioxide, carbon storage, climate change, trace gases

\begin{abstract}
Over the past three decades, one issue that has received significant attention from the scientific community is climate change and the possible impacts on the global environment. Increased atmospheric carbon dioxide $\left(\mathrm{CO}_{2}\right)$ concentration along with other trace gases [i.e., methane $\left(\mathrm{CH}_{4}\right)$ and nitrous oxide $\left(\mathrm{N}_{2} \mathrm{O}\right)$ ] are widely believed to be the driving factors behind global warming. Much of the work on reducing greenhouse gas emissions and carbon (C) sequestration has been conducted in row crop and forest systems; however, virtually no work has focused on contributions from sectors of the specialty crop industry such as ornamental horticulture. Ornamental horticulture is an industry that impacts rural, suburban, and urban landscapes. Although this industry may have some negative impacts on the global environment (e.g., $\mathrm{CO}_{2}$ and trace gas efflux), it also has potential to reduce greenhouse gas emissions and increase $C$ sequestration. The work described here outlines the causes and environmental impacts of climate change, the role of agriculture in reducing emissions and sequestering $C$, and potential areas in ornamental horticulture container-grown plant production in which practices could be altered to increase $\mathbf{C}$ sequestration and mitigate greenhouse gas emissions.
\end{abstract}

There is widespread belief among the scientific community that anthropogenic-driven climate change is occurring and that it poses a serious global threat. Atmospheric concentrations of the three most important long-lived greenhouse gases (GHG) have increased dramatically over the past 255 years (IPCC, 2007). Carbon dioxide, $\mathrm{CH}_{4}$, and $\mathrm{N}_{2} \mathrm{O}$ concentrations in the atmosphere have increased by $\approx 35 \%$, $155 \%$, and $18 \%$, respectively, since 1750 (Dlugokencky et al., 2005; Keeling and Whorf, 2005; Prinn et al., 2000). Increases in GHG are widely believed to be the main factor causing global warming (Florides and Christodoulides, 2008). Fossil fuel combustion along with land

Received for publication 25 Aug. 2010. Accepted for publication 9 Dec. 2010.

This work was supported by the USDA-ARS Floriculture and Nursery Research Initiative.

We thank Barry Dorman for technical assistance.

${ }^{1}$ Graduate Research Assistant.

${ }^{2}$ Plant Physiologist.

${ }^{3}$ Plant Pathologist.

${ }^{4}$ Soil Scientist and Research Leader.

${ }^{5}$ Professor of Horticulture.

${ }^{6}$ Associate Professor of Horticulture.

${ }^{7}$ To whom reprint requests should be addressed. e-mail gillic1@auburn.edu. hardest by temperature change. Shifts in temperatures and precipitation patterns could benefit some cropping systems while hindering others. Some agricultural production systems may be sensitive to even small shifts in global temperature, requiring adaptation of management of available resources for sustained and successful economic development (Watson et al., 1998). Major technological advancements have been made in the agriculture industry in the last few decades such as improved pest control, development of genetically modified crops, and improved breeding techniques, which have produced the highest crop yields to date. However, modern agriculture may have difficulty meeting food demands of an expanding world population (U.S. Census Bureau, 2008). Even small reductions in yield of major food sources (e.g., corn, rice, wheat) could have devastating impacts, particularly in impoverished areas (Pimentel et al., 1996). Currently, researchers in almost every industry are developing strategies to reduce GHG emissions and the negative impacts of increased global temperature.

\section{Greenhouse Gas Emissions from Agricultural Production}

The agriculture industry in the United States is one of the largest contributors to GHG emissions behind energy production (Johnson et al., 2007). Carbon dioxide, $\mathrm{CH}_{4}$, and $\mathrm{N}_{2} \mathrm{O}$ are the three most important GHG as a result of their increasing atmospheric concentrations and the fact that these increases are mainly the result of human activities. Emissions from agriculture collectively account for an estimated onefifth of the annual increase in global GHG emissions. When land use changes involving clearing of land, biomass burning, and soil degradation are included, the overall radiative forcing from agriculture production is one-third of the manmade greenhouse effect (Cole et al., 1997).

Increased $\mathrm{CO}_{2}$ concentrations since the industrial revolution are mainly the result of emissions from the combustion of fossil fuels, gas flaring, and cement production (IPCC, 2007). Agriculture production and biomass burning also contribute to $\mathrm{CO}_{2}$ emissions as does land use changes such as deforestation (Houghton, 2003). Deforestation globally released an estimated 136 billion tons of $\mathrm{C}$ or $33 \%$ of total emissions between 1850 and 1998, which exceeds any other anthropogenic activity besides energy production (Watson et al., 2000).

Agriculture is also considered a major contributor of $\mathrm{CH}_{4}$ and $\mathrm{N}_{2} \mathrm{O}$ and is estimated to produce $\approx 50 \%$ and $70 \%$, respectively, of the total manmade emissions (Cole et al., 1997). The primary agricultural sources of $\mathrm{CH}_{4}$ are enteric fermentation in ruminant animals, flooded rice fields, and biomass burning (Cole et al., 1997; Johnson et al., 1993; USDA, 2008); other major anthropogenic sources include landfills and natural gas emissions (Mathez, 2009). Managed livestock waste can also release $\mathrm{CH}_{4}$ and $\mathrm{N}_{2} \mathrm{O}$ through the biological breakdown of organic compounds such as 
those found in manure (USDA, 2008). Although $\mathrm{N}_{2} \mathrm{O}$ forms naturally in soils and oceans through microbial processes, it is also a byproduct of agriculture and fossil fuel combustion (Mathez, 2009). The radiative forcing of $\mathrm{N}_{2} \mathrm{O}$ is increasing from the large-scale production and application of inorganic nitrogen $(\mathrm{N})$ fertilizers, resulting in $80 \%$ of the total $\mathrm{N}_{2} \mathrm{O}$ emissions in the United States (Mosier et al., 2003).

Many scientists believe that emissions from agriculture must be reduced to slow climate change. Opportunities for reducing GHG emissions in agriculture have been the focus of much research (Cole et al., 1997; Kroeze and Mosier, 2000; Lal et al., 1998; Lin et al., 1994; Paustian et al., 2000; Smith et al., 1998). However, it is widely believed that emissions reduction alone will not be sufficient to curtail the negative impacts on the environment; longterm capture and storage (sequestration) of $\mathrm{C}$ are necessary. Carbon sequestration in plants is commonly referred to as terrestrial $\mathrm{C}$ sequestration, a process in which photosynthesis removes $\mathrm{CO}_{2}$ from the atmosphere and stores it in plant biomass. Carbon is transferred to the substrate (growing media or soil) through plant litter, roots, and exudates and some is stored (Getter et al., 2009). Carbon transfer from plant biomass into soil organic matter is a key sequestration pathway and is a significant research area in agriculture. To date, most of the work on reducing GHG emissions and C sequestration has been conducted in row crop and forest systems with virtually no work on contributions (either positively or negatively) from specialty crop industries such as ornamental horticulture.

\section{Carbon Sequestration Potential in Ornamental Horticulture Systems}

Ornamental horticulture is an industry that impacts the landscape of rural, suburban, and urban environments. The economic impact of the "green industry" (nursery, greenhouse, and sod) is $\$ 148$ billion annually in the United States (Hall et al., 2005) and was $\$ 2.8$ billion in Alabama alone in 2008 (AAES, 2009). In the United States, it is one of the fastest growing businesses, expanding even during recessionary periods; it generates 1.9 million jobs, $\$ 64.3$ billion in labor income, and $\$ 6.9$ billion in indirect business taxes (Hall et al., 2005). In 2006, there were 7300 producers in the top 17 states, occupying approximately one-half million acres (USDA, 2007). In addition, non-agricultural land (e.g., urban and suburban) in the United States comprises 150 million areas (Lubowski et al., 2006), a significant proportion of which is (or could be) planted with ornamental trees and shrubs. Although the ornamental horticulture industry may be small relative to other sectors of agriculture (e.g., corn), it is one of the fastest growing sectors in agriculture and its potential impacts on climate change (either positively or negatively) have been virtually ignored.

There is need for the ornamental horticulture industry as well as other sectors of agriculture to examine how current production practices can be altered to reduce GHG emissions and sequester $\mathrm{C}$. This will not only improve the environment, but these measures could soon be required by law. In Apr. 2007, the U.S. Supreme Court concluded that GHG meet the definition of air pollutants as stated in the 1970 Clean Air Act Extension; the U.S. Environmental Protection Agency (EPA) gained authority to regulate GHG emitted from new motor vehicles (mobile sources). This decision could become significant because the EPA may decide to strictly regulate and enforce limits on other (including industrial) sources of GHG emissions (EPA, 2008). There is also speculation that legislation limiting $\mathrm{CO}_{2}$ and other GHG emissions could occur in the near future. All sectors of agriculture need to examine alternative management practices that comply with possible new legislation while reducing GHG emissions and sequestering $\mathrm{C}$ without decreasing productivity or profits.

The ornamental horticulture industry has the potential to benefit financially from reducing GHG emissions and its $\mathrm{C}$ footprint by altering management practices. Currently, there is interest in numerous agricultural sectors to earn new income from emerging $\mathrm{C}$ trading markets as well as new government incentives for reducing GHG emissions. The EPA has begun partnerships and programs to promote opportunities to conserve fossil fuels, improve energy efficiency, recover $\mathrm{CH}_{4}$, and sequester $\mathrm{C}$; these include tax incentives for some industries. Beginning in 2003, the U.S. Department of Agriculture (USDA) began providing targeted incentives to encourage wider use of land management practices that remove $\mathrm{C}$ from the atmosphere or reduce GHG emissions. In 2006, the federal government proposed energy tax incentives to promote GHG emission reductions totaling \$524 million in fiscal year 2006 and $\$ 3.6$ billion over 5 years. These included tax credits for the purchase of hybrid cars and use of solar heating systems, energy from landfill gas, and electricity produced from wind and biomass (EPA, 2008).

All sectors of the agricultural community could potentially profit by incorporating these "green" technologies into their production systems. Organizations such as the National Farmer's Union (NFU) have implemented new programs [in conjunction with the Chicago Climate Exchange's (CCE) Carbon Credit Program] in which farmers may be paid to reduce $\mathrm{C}$ emissions or to provide $\mathrm{C}$ credits to industries wanting to offset their $\mathrm{C}$ footprint (CCE, 2009; NFU, 2009). Other similar programs such as the Regional Greenhouse Initiative (a cooperative effort among 10 northeastern U.S. states) allows utility companies to apply offsets (i.e., farmers turning cropland into permanent pasture, planting of trees, burning of $\mathrm{CH}_{4}$ in landfills, etc.) toward their compliance target of a $10 \%$ emission reduction between 2009 and 2018 (Schmidt, 2009). In 2008, Missouri farmers adopting no-till could receive a $\mathrm{C}$ credit of 0.5 to $1.3 \mathrm{t} / \mathrm{ha} /$ year and cropland converted to grassland received $\mathrm{C}$ credits of $2.2 \mathrm{t} / \mathrm{ha} /$ year. In $2007, \mathrm{C}$ contracts were selling for $\$ 4.40$ per tonne, whereas in
2008 , the price was $\$ 6.60$ per tonne. However, should GHG become regulated, the price of $\mathrm{C}$ credits is likely to increase, translating to more income for farmers participating in these programs. In Europe, where GHG emissions are limited, $\mathrm{C}$ is valued at over $\$ 33$ per tonne (Massey, 2008). For ornamental horticulture to reduce GHG emissions and benefit from such emerging programs, baseline estimates of $\mathrm{GHG}$ emissions and $\mathrm{C}$ sequestration from current production practices must be established.

The intent of this article is to explore GHG mitigation and sequestration possibilities in ornamental horticulture production. We focus on three aspects: 1) media used in containergrown plant production; 2) fertilization practices; and 3) the ability of ornamental species to sequester $\mathrm{C}$ after being planted into the landscape.

\section{Media for Container-grown Plant Production}

Changes in row crop management such as minimizing soil disturbance (i.e., no-tillage) and increasing plant residues (including use of cover crops) have been shown to enhance the $\mathrm{C}$ sequestration potential in agronomic systems (Lal, 2007; Smith et al., 1998). Opportunities also exist to enhance $\mathrm{C}$ sequestration in ornamental container-grown plant production systems. Containerized nursery crops are a major sector of the ornamental horticulture industry in which plants are grown in a predominantly pine bark-based medium. Pine bark is composed largely of organic C, having a $\mathrm{C}$ concentration greater than $60 \%$ compared with $\approx 3 \% \mathrm{C}$ found in field soils (Simmons and Derr, 2007). When containerized ornamentals are planted into the landscape, a large amount of $\mathrm{C}$ is transferred belowground (sequestered). Uncertainty remains regarding how long this $\mathrm{C}$ will remain sequestered. If net primary plant biomass production exceeds the degradation rate of this transferred material, the microecosystems created by such outplantings would be net $\mathrm{C}$ sinks, at least in the short term (Getter et al., 2009). It is necessary to determine the number of container-grown plants (as well as their container sizes) produced annually to estimate the amount of $\mathrm{C}$ being sequestered. This would generate critical data for the horticulture industry. Although much is known concerning the annual economic impact of the container-grown plant industry, little data exist on the numbers and sizes of containers used in production systems regionally or nationally.

A nursery survey was conducted to begin quantifying the amount of $\mathrm{C}$ used in container media. Thirteen Alabama nurseries, representing $\approx 50 \%$ of the total state containergrown plant production, were polled at regional scientific meetings, on-farm visits, and through the Alabama Agricultural Extension Service. Growers were asked how many containergrown plants they produced each year, what size containers were used (e.g., \#1, \#3, \#5, etc.), and the primary potting media used (e.g., pine bark, pine bark + sand, pine bark + 
peat) (Table 1). All growers polled used pine bark as their primary growth medium (Table 2). Although pine bark + other accounted for almost $42 \%$ of the media used (Table 2), the amendments were usually sand or peat in very small volumes (less than 10\%). The survey indicated that $\approx 72,000 \mathrm{~m}^{3}$ of pine bark was used to produce container-grown nursery crops; given that the survey represented only half of the state's production, this estimate could be doubled $\left(140,000\right.$ to $\left.150,000 \mathrm{~m}^{3}\right)$. Because pine bark has a very high $\mathrm{C}$ concentration $(49.2 \%$ in our analysis; with a density of $\left.0.24 \mathrm{~g} \cdot \mathrm{cm}^{-3}\right)$, this represents a significant amount of $\mathrm{C}(16,500$ to $17,700 \mathrm{Mg} \mathrm{C})$ potentially placed belowground.

Although the $\mathrm{C}$ sequestration potential of pine bark-based media is needed, recent evidence suggests that future availability of pine bark could be limited ( $\mathrm{Lu}$ et al., 2006) and researchers are beginning to search for alternatives. New alternative growing media such as WholeTree (WT) and clean chip residual (CCR) have been shown to be suitable replacements for pine bark-based growing media (Boyer et al., 2008, 2009; Fain et al., 2008). Our analyses found these media have high wood content ( $\approx 90 \%$ for $\mathrm{WT}, \approx 40 \%$ for CCR) and have $\mathrm{C}$ concentrations similar to pine bark (C was $47.8 \%, 46.9 \%$, and $49.2 \%$ for WT, CCR, and pine bark, respectively). Future research is needed to determine the $\mathrm{C}$ storage potential of these various growth media along with decomposition studies to determine the longevity of this $\mathrm{C}$ storage. This information will be crucial in determining potential benefits to producers in terms of future " $\mathrm{C}$ cap and trade" issues.

Another issue in $\mathrm{C}$ sequestration will involve who gets credit for the container media (and other products such as bark and straw mulches) used in the ornamental horticulture industry because these products are produced primarily from forestry operations. In this regard, we are speaking more to which industry will get credit, in " $\mathrm{C}$ footprint" terms, than to who should receive any " $\mathrm{C}$ cap and trade" payments. We believe this will depend on several factors. First, had these materials (i.e., container media and mulches) not been used by the ornamental industry, what would their fate have been? If the material was left on-site, the forestry operation should receive the credit. However, if the material was burned as a fuel source at forest products mills or burned on forest harvest sites, this would result in no $\mathrm{C}$ sequestration; thus, placing it into landscape settings would result in significant increases in $\mathrm{C}$ sequestration related to horticultural activities. A second consideration involves simple economics. If forest products companies are selling these materials to the horticultural producers, they have already made a financial gain and should not receive any $\mathrm{C}$ credit. It is then the horticultural and landscape industries, in addition to homeowners, which are placing this purchased $\mathrm{C}$ in or on the ground and are "sequestering" it and the credit should belong to them. Which industry receives credit for this $\mathrm{C}$ will likely result in substantial debate.

\section{Fertilization Practices}

Fertilization is another aspect of ornamental container-grown plant production that could be altered to reduce GHG emissions. Nitrogen fertilizer applications currently account for almost $80 \%$ of total agricultural $\mathrm{N}_{2} \mathrm{O}$ emissions (Millar et al., 2010). Production of $\mathrm{N}$ fertilizers is an energy-intensive process resulting in emission of GHG. In row cropping systems, research has shown that fertilizer rate, placement, and timing application with plant demand all have a major influence on $\mathrm{N}_{2} \mathrm{O}$ emissions (Cole et al., 1997; Millar et al., 2010; Smith et al., 2007). Although this will likely be the case in nursery container-grown plant production, no research exists to support this contention.

As part of the survey discussed previously, growers were asked to describe their fertilization methods (e.g., topdress, incorporate, dibble). Topdressing refers to placement of the fertilizer on the top of the media surface after planting; incorporation refers to incorporating the fertilizer in the potting media before planting; and dibbling refers to placing the fertilizer in a small hole formed in the potting media. Survey results show that almost all Alabama growers of containerized plants prefer to dibble or incorporate fertilizer at potting and then topdress later in the season as needed; this is consistent with the best management practices (BMPs) described by Yeager et al. (2007) (Table 2). Although the BMP Guide is an excellent tool to follow for cost-effective production of healthy containergrown nursery crops, none of the BMPs consider GHG emissions; it is possible that current BMPs could be altered to reduce GHG emissions. Nitrogen placement in agriculture (e.g., banding versus broadcast) has been shown to reduce surface $\mathrm{N}$ loss and increase plant $\mathrm{N}$ use (Paustian and Babcock, 2004). Nitrogen placement can also affect $\mathrm{N}$ movement and use in ornamental container-grown plant production (Fain and Knight, 2006; Keever and Cobb, 1990; Warren et al., 2001). For example, dibbling fertilizer close to the liner rootball might reduce $\mathrm{N}$ leaching and increase plant $\mathrm{N}$ use, thereby reducing the amount of fertilizer used compared with methods such as incorporation. In addition, topdressing the plants only at peak growing times for each species could increase $\mathrm{N}$ use efficiency and reduce fertilizer use. The effect of altered $\mathrm{N}$ fertilization practices on growth, $\mathrm{N}$ use efficiency, $\mathrm{N}$ leaching, and $\mathrm{N}_{2} \mathrm{O}$ emissions requires investigation to fine-tune future BMPs for productivity, profitability, and environmental stewardship.

Other factors in fertilization practices could impact $\mathrm{N}$ losses (leaching and $\mathrm{N}_{2} \mathrm{O}$ emissions). For example, if a higher fertilizer formulation is used $(20 \mathrm{~N}-10 \mathrm{P}-10 \mathrm{~K}$ versus $8 \mathrm{~N}-8 \mathrm{P}-8 \mathrm{~K}$ ), one might expect increased $\mathrm{N}_{2} \mathrm{O}$ emissions; however, if application rates are reduced, $\mathrm{N}_{2} \mathrm{O}$ emissions might not be changed. On the other hand, high analysis fertilizers are less energy-intensive to produce, package,

Table 1. Estimation of container-grown plant production in Alabama by size of container sold annually by top producers in the state.

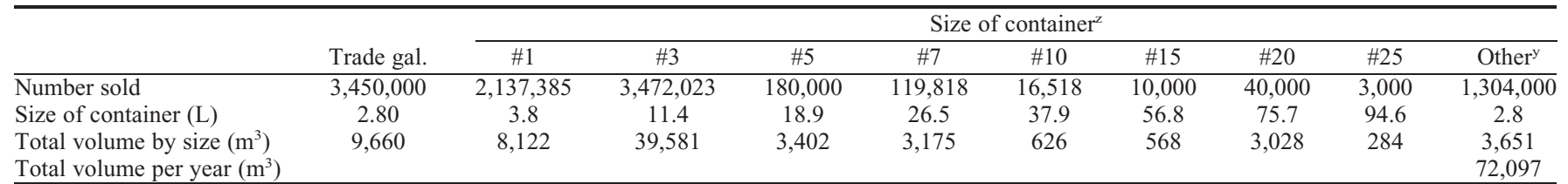

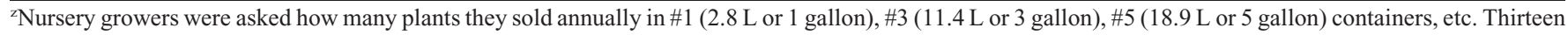
of the top container-grown plant production nurseries were polled in person at regional industry meetings and during on-farm visits. All of the nurseries polled participated in the survey.

${ }^{\mathrm{y}}$ Other = plants that range from smaller than trade gallon to larger that $\# 25$. A conservative size $2.8 \mathrm{~L}$ was used to estimate total volume of media used in these containers.

Table 2. Fertilization methods, potting media, and growth rate of plants produced in Alabama container-grown plant nurseries.

\begin{tabular}{|c|c|c|c|c|c|c|}
\hline \multicolumn{2}{|c|}{ Potting media ${ }^{z}$} & \multicolumn{2}{|c|}{ Fertilization method } & \multicolumn{3}{|c|}{ Growth rate of plants sold ${ }^{y}$} \\
\hline $100 \%$ PB & $\mathrm{PB}+$ other & Incorporate then topdress & Dibble then topdress & Slow & Medium & Fast \\
\hline
\end{tabular}

${ }^{2} \mathrm{~PB}+$ other indicates media in which PB was amended with other materials (sand, peat, wood shavings, etc.), usually at very small volumes (less than $10 \%$ ). ${ }^{y}$ Nursery growers asked what percentage of their crops were slow- (less than $0.30 \mathrm{~m}$ per year), medium- (0.30 to $0.91 \mathrm{~m}$ per year), or fast-growing (greater than $0.91 \mathrm{~m}$ per year). Thirteen of the top container-grown plant production nurseries were polled in person at regional industry meetings and during on-farm visits. All of the nurseries polled participated in the survey. 
ship, and apply (Gellings and Parmenter, 2008). In addition, most growers use high analysis, slow-release or encapsulated fertilizers, which could affect $\mathrm{N}$ losses. Use of these types of fertilizers will affect GHG during production as well as application; however, research is needed to determine the best option for optimizing growth and minimizing $\mathrm{N}_{2} \mathrm{O}$ emissions from fertilizers in the horticulture industry both during production and after outplanting. Another interacting factor that could impact $\mathrm{N}$ losses is the frequency and amount of irrigation. Excessive irrigation could increase both $\mathrm{N}$ leaching and $\mathrm{N}_{2} \mathrm{O}$ emissions. The effects of irrigation on $\mathrm{N}$ losses in container-grown plant production systems require investigation to develop BMPs not only for reducing $\mathrm{N}_{2} \mathrm{O}$ emissions, but also for water conservation, an issue becoming critical in a changing climate.

\section{Carbon Sequestration Potential of Ornamental Plants in the Landscape}

Another potential $\mathrm{C}$ sink in ornamental plant production is the ability of plants to store $\mathrm{C}$ in biomass. Previous research has shown that urban forests have a significant potential for removing $\mathrm{CO}_{2}$ from the atmosphere and sequestering $\mathrm{C}$ in standing biomass (Nowak, 1993). Rowntree and Nowak (1991) estimated that urban forests in the United States sequester $\approx 712$ million tonnes of $\mathrm{C}$. In addition to storing $\mathrm{C}$, urban trees cool ambient air and provide shade, which reduces energy costs (Rowntree and Nowak, 1991). Simpson and McPherson (1998) reported that in Sacramento County, CA, a utilities-sponsored tree planting program resulted in an estimated annual savings of \$24 per mature tree. As energy prices rise and trees grow, they will become even more valuable. In addition, green roof systems have been shown to reduce energy costs as well as successfully sequester C (Getter et al., 2009).

Aside from trees, no research has addressed the potential benefits of shrubs, perennials, and other ornamental nursery species to the environment, including $\mathrm{C}$ storage. Most ornamental shrubs require little or no management inputs and often accumulate biomass quickly, making them a potential major $\mathrm{C}$ sink. In our survey, producers categorized their crops by those that were fast- (greater than $0.91 \mathrm{~m}$ per year), medium- (0.30 to $0.91 \mathrm{~m}$ per year), or slowgrowing (less than $0.31 \mathrm{~m}$ per year). Fast-, medium-, and slow-growing species made up $19.8 \%, 56.6 \%$, and $23.6 \%$, respectively, of container-grown nursery crops (Table 2 ). Most of the trees described in the studies would be considered fast or medium growers and would accumulate more biomass (more $\mathrm{C}$ storage potential) than shrubs. However, most landscapes have more shrubs than trees. It is possible that, in any given landscape, the total C accumulated in shrubs could be greater than that in trees.

To determine the $\mathrm{C}$ "footprint" or $\mathrm{C}$ budget of the ornamental horticulture industry, $\mathrm{C}$ "costs" or C losses must also be considered. The $\mathrm{C}$ costs associated with both production and application of pesticides, fertilizers, irriga- tions, etc., must be taken into consideration. These figures are likely to be relatively low for the ornamental horticulture industry because much work (i.e., weed control, application of other pesticides, fertilization) is done by hand as opposed to agriculture where most of this work is conducted with machines. Carbon losses (from decomposition of mulches, trimmings, media substrates, etc., along with those associated with plant respiration) must also be considered. For example, in studies of managed turfgrass systems, it was found that, although irrigation and fertilization enhance productivity and $\mathrm{C}$ storage, soil GHG emissions in these systems can increase. It was suggested that managed turf systems are not often considered $\mathrm{C}$ sinks given the amount of fossil fuel needed to mow, fertilize, and apply pesticides to these systems (Townsend-Small and Czimczik, 2010). At present, it is not known if the ornamental horticulture industry will represent a net source or sink for C.

Production and outplanting of ornamental nursery crops could still prove to be a significant $\mathrm{C}$ sink given the quantity of $\mathrm{C}$ accumulated in biomass and that added to soil as growth media. At present, however, this is unknown as is how the $\mathrm{C}$ sequestration ability of the ornamental horticulture industry compares with that of other systems (e.g., row crops and forests). Nonetheless, the ornamental horticulture industry provides the average U.S. homeowner an ability to participate in reducing their $\mathrm{C}$ footprint by landscaping their yards while increasing property values in the process.

\section{Conclusions}

There remains much uncertainty regarding the best practices for lowering GHG emissions and increasing $\mathrm{C}$ storage in the ornamental horticulture industry; this is an area deserving investigation. Changes in production practices that have been shown to reduce GHG emissions and increase $\mathrm{C}$ storage in other agriculture fields could possibly be applicable to nursery container-grown production. As data become available, the role of the ornamental horticulture industry on climate change (both positive and negative) will begin to be elucidated. Industry leaders and growers can then begin to fine-tune BMPs to maximize productivity and profitability while minimizing GHG emissions. Research is needed to provide the industry with the necessary tools for adapting to future legislation that could cap GHG emissions and provide growers opportunities in the emerging $\mathrm{C}$ trading and offsets market. Continued investigation is also needed to discover profitable and environmentally sustainable ways to grow plants. In addition, determining $\mathrm{C}$ sequestration potential of various landscape species when planted into urban and suburban landscapes could provide homeowners a means of directly contributing to mitigation of climate change.

\section{Literature Cited}

AAES. 2009. Economic impact of Alabama's green industry: Green industry growing. Spec. Rept.
No. 7. Alabama Agricultural Experiment Station, Auburn University, AL.

Boyer, C.R., G.B. Fain, C.H. Gilliam, T.V. Gallagher, H.A. Torbert, and J.L. Sibley. 2008. Clean chip residual: A substrate component for growing annuals. HortTechnology 18:423-432.

Boyer, C.R., C.H. Gilliam, G.B. Fain, T.V. Gallagher, H.A. Torbert, and J.L. Sibley. 2009. Production of woody nursery crops in clean chip residual substrate. J. Environ. Hort. 27:56-62.

Chicago Climate Exchange. 2009. General offset program provisions. 5 Nov. 2009. <http://www. chicagoclimatex.com/docs/offsets/CCX_General_ Offset Program Provisions_Final.pdfs.

Cole, C.V., J. Duxbury, J. Freney, O. Heinemeyer, K. Minami, A. Mosier, K. Paustian, N. Rosenburg, N. Sampson, D. Sauerbeck, and Q. Zhao. 1997. Global estimates of potential mitigation of greenhouse gas emissions by agriculture. Nutr. Cycl. Agroecosyst. 49:221-228.

Dlugokencky, E.J., R.C. Myers, P.M. Lang, K.A. Masarie, A.M. Crotwell, K.W. Thoning, B.D. Hall, J.W. Elkins, and L.P. Steele. 2005. Conversion of NOAA atmospheric dry air $\mathrm{CH}_{4}$ mole fractions to a gravimetrically prepared standard scale. J. Geophys. Res. 110:D18306, doi: 10.1029/ 2005JD006035.

Douglas, L. 2004. Global warming. Facts on File, Inc., New York, NY.

Environmental Protection Agency. 2008. Advance notice of proposed rulemaking: Regulating greenhouse gas emissions under the clean air act. 12 Apr. 2009. <http://www.epa.gov/climatechange/ anpr.html>.

Fain, G.B., C.H. Gilliam, J.L. Sibley, and C.R Boyer. 2008. Whole Tree substrates derived from three species of pine in production of annual vinca. HortTechnology 18:13-17.

Fain, G.B. and P.R. Knight. 2006. Irrigation and fertilizer placement affects plant and weed growth in container tree production. HortScience 41:1026 (abstr.).

Florides, G.A. and P. Christodoulides. 2008. Global warming and carbon dioxide through sciences. J. Environ. Intl. 35:390-401.

Gellings, C.W. and K.E. Parmenter. 2008. Energy efficiency in fertilizer production and use, $\mathrm{p}$. 123-136. In: Gellings, C.W. (ed.). Efficient use and conservation of energy. EOLSS Publishers, Oxford, UK.

Getter, K.L., D.B. Rowe, G.P. Robertson, B.M. Cregg, and J.A. Anderson. 2009. Carbon sequestration potential of extensive green roofs. J. Environ. Sci. Technol. 43:7564-7570.

Hall, C.R., A.W. Hodges, and J.J. Haydu. 2005. Economic impacts of the green industry in the U.S. 4 June 2010. <http://www.utextension.utk. edu/hbin/greenimipact.html $>$.

Houghton, R.A. 2003. Revised estimates of the annual net flux of carbon to the atmosphere from changes in land use and land management. Tellus B Chem. Phys. Meterol. 55:378390.

IPCC. 2001. Climate change 2001: The scientific basis, contribution of Working Group I to the third assessment report of the Intergovernmental Panel on Climate Change. Houghton, J.T., Y. Ding, D.J. Griggs, M. Noguer, P.J. van der Linden, X. Dai, K. Maskell, and C.A. Johnson (eds.). Cambridge University Press, Cambridge, UK.

IPCC. 2007. Contribution of Working Group II to the Fourth Assessment Report of the Intergovernmental Panel on Climate Change. Parry, M.L., O.F. Canziani, J.P. Palutikof, P.J. van der Linden, and C.E. Hanson (eds.). Cambridge University Press, Cambridge, UK.

Johnson, D.E., T.M. Hill, G.M. Ward, K.A. Johnson, M.E. Branine, B.R. Carmean, and D.W. Lodman. 
1993. Ruminants and other animals, p. 199-299. In: Khalil, M.A.K. (ed.). Atmospheric methane: Sources, sinks, and role in global change. Springer-Verlag, New York, NY.

Johnson, J.M., A.J. Franzleubbers, S.L. Weyers, and D.C. Reicosky. 2007. Agriculture opportunities to mitigate greenhouse gas emissions. Environ. Pollut. 150:107-124.

Keeling, C.D. and T.P. Whorf. 2005. Atmospheric $\mathrm{CO}_{2}$ records from sites in the SIO air sampling network. In: Trends: A compendium of data on global change. Carbon Dioxide Information Analysis Center, Oak Ridge National Laboratory, U.S. Department of Energy, Oak Ridge, TN. 16 Aug. 2010. <http://gcmd.nasa.gov/records/ GCMD_CDIAC_CO2_SIO.html $>$.

Keever, G.J. and G.S. Cobb. 1990. Plant response to container planting method and media. J. Environ. Hort. 8:189-192.

Kroeze, C. and A.R. Mosier. 2000. New estimates for emissions of nitrous oxide, p. 45-64. In: van Ham, J.E.A. (ed.). Non- $\mathrm{CO}_{2}$ greenhouse gases: Scientific understanding, control and implementation. Kluwer Academic Publishers, Dordrecht, The Netherlands.

Lal, R. 2004. Soil carbon sequestration to mitigate climate change. Geoderma 123:1-22.

Lal, R. 2007. Carbon management in agricultural soils. Mitig. Adapt. Strategies Glob. Change 12: 303-322.

Lal, R., J.M. Kimble, R.F. Follett, and C.V. Cole. 1998. The potential of U.S. cropland to sequester carbon and mitigate the greenhouse effect. Lewis Publishers, Boca Raton, FL.

Lin, E., H. Dong, and Y. Li. 1994. Methane emissions of China: Agricultural sources and mitigation options, p. 405-410. In: van Ham, J. et al. (ed.). Non- $\mathrm{CO}_{2}$ greenhouse gases. Kluwer Academic Publishers, Dordrecht, The Netherlands.

Lu, W., J.L. Sibley, C.H. Gilliam, J.S. Bannon, and Y. Zhang. 2006. Estimation of U.S. bark generation and implications for horticultural industries. J. Environ. Hort. 24:29-34.

Lubowski, R.N., M. Vesterby, S. Bucholtz, A. Baez, and M.J. Roberts. 2006. Major uses of land in the United States, 2002. Economic Information Bulletin No. EIB-14. Economic Research Service, USDA.
Massey, R. 2008. Agriculture and carbon credits. Integrated Pest Crop Mgt. 18:47-52.

Mathez, E.A. 2009. Climate change. Columbia University Press, New York, NY.

Millar, N., G.P. Robertson, P.R. Grace, R.J. Gehl, and J.P. Hoben. 2010. Nitrogen fertilizer management for $\mathrm{N}_{2} \mathrm{O}$ mitigation in intensive corn (maize) production: An emission reduction protocol for U.S. midwest agriculture. Mitig. Adapt. Strat. Global Change 15:185-204.

Mosier, A.R., G.A. Peterson, and L.A. Sherrod. 2003. Mitigating net global warming potential $\left(\mathrm{CO}_{2}, \mathrm{CH}_{4}\right.$ and $\left.\mathrm{N}_{2} \mathrm{O}\right)$ in upland crop productions. Proc. Methane and Nitrous Oxide International Workshop. p. 273-280.

National Farmers Union. 2009. Carbon credit program. 5 Nov. 2009. <http://nfu.org/issues/ environment/carbon-credits $>$.

Nowak, D.J. 1993. Atmospheric carbon reduction by urban trees. J. Environ. Mgt. 37:207-217.

Paustian, K. and B.A. Babcock. 2004. Climate change and greenhouse gas mitigation: Challenges and opportunities for agriculture. Task Force Report 141. Council for Agricultural Science and Technology, Ames, IA.

Paustian, K., J. Six, E.T. Elliot, and H.W. Hunt. 2000. Management options for reducing carbon dioxide emissions from agricultural soils. Biogeochem. J. 48:147-163.

Pimentel, D., X. Huang, A. Cordova, and M. Pimentel. 1996. Impact of population growth on food supplies and environment. 23 Nov. 2010. <http://www.dieoff.org/page57.htm>.

Prinn, R.G., R.F. Weiss, P.J. Fraser, P.G. Simmonds, D.M. Cunnold, F.N. Alyea, S. O'Doherty, P. Salameh, B.R. Miller, J. Huang, R.H.J. Wang, D.E. Hartley, C. Harth, L.P. Steele, G. Sturrock, P.M. Midgely, and A. McCulloch. 2000. A history of chemically and radiatively important gases in air deduced from ALE/GAGE/AGAGE. J. Geophys. Res. 105:17751-17792.

Rowntree, R.A. and D.J. Nowak. 1991. Quantifying the role of urban forests in removing atmospheric carbon dioxide. J. Abor. 17:269-275.

Schmidt, C.W. 2009. Carbon offsets. Environ. Health Perspect. 117:63-68.

Simmons, L.D. and J.F. Derr. 2007. Pendimethalin movement through pine bark compared to field soil. Weed Technol. 21:873-876.
Simpson, J.R. and E.G. McPherson. 1998. Simulation of tree shade impacts on residential energy use for space conditioning in Sacromento. Atmos. Environ. 32:69-74.

Smith, K.A., I.P. McTaggart, and H. Tsuruta. 2007. Emissions of $\mathrm{N}_{2} \mathrm{O}$ and $\mathrm{NO}$ associated with nitrogen fertilization in intensive agriculture and the potential for mitigation. Soil Use Mgt. 13:296-304.

Smith, P., D.S. Powlson, M.J. Glendining, and J.U. Smith. 1998. Preliminary estimates of the potential for carbon mitigation in European soils through no-till farming. Glob. Change Biol. 4:679-685.

Townsend-Small, A. and C.I. Czimczik. 2010 Carbon sequestration and greenhouse gas emissions in urban turf. Geophys. Res. Lett. 37:L02707, doi: 10.1029/2009GL041675.

U.S. Census Bureau. 2008. World population information. 23 Nov. 2010. <http://www.census. gov/ipc/www/idb/worldpopinfo.html>.

USDA. 2007. Nursery crops 2006 summary. Publ. No. Sp Cr 6-3. U.S. Department of Agriculture, National Agriculture Statistics Service.

USDA. 2008. U.S. agriculture and forestry greenhouse gas inventory: 1990-2005. 29 Mar. 2009. $<$ http://www.usda.gov/oce/global_change/AFGG_ Inventory/USDA_GHG_Inventory.pdf >

Warren, S.L., T.E. Bilderback, and H.H. Kraus. 2001. Method of fertilizer application affects nutrient losses of controlled release fertilizers. Acta Hort. 548:349-355.

Watson, R.T., I.R. Noble, B. Bolin, N.H. Ravindranath, D.J. Verardo, and D.J. Dokken. 2000. Land use, land-use change, and forestry, 2000. Special report of the Intergovernmental Panel on Climate Change. Cambridge University Press, Cambridge, UK.

Watson, R.T., M.C. Zinyonera, and R.H. Moss; IPCC Working Group II. 1998. The regional impacts of climate change: An assessment of vulnerability. Cambridge University Press, New York, NY

Yeager, T., T. Bilderback, D. Fare, C. Gilliam, J. Lea-Cox, A. Niemiera, J. Ruter, K. Tilt, S. Warren, T. Whitwell, and R. Wright. 2007. Best Management Practices: Guide for producing nursery crops. 2nd Ed. Southern Nursery Assn., Atlanta, GA. 